\title{
Microbial activity was greater in soils added with herb residue vermicompost than chemical fertilizer
}

\author{
Meirong Lv ${ }^{1,2}$, Jingjuan $\mathrm{Li}^{1,3}$, Weixin Zhang ${ }^{4}$, Bo Zhou ${ }^{1,5}$, Jun Dai ${ }^{1, *}$, Chi Zhang ${ }^{1, *}$ \\ 1 The College of Natural Resources and Environment, South China Agricultural University, Guangzhou 510650, China \\ 2 Institute of Oceanographic Instrumentation, Qilu University of Technology (Shandong Academy of Sciences), Shandong Provincial Key \\ Laboratory of Marine Monitoring Instrument Equipment Technology, National Engineering and Technological Research Center of Marine \\ Monitoring Equipment, Qingdao 260000, China \\ 3 Agricultural Technology Promotion Center of Huicheng District, Huizhou 516008, China \\ 4 Key Laboratory of Geospatial Technology for Middle and Lower Yellow River Regions, Ministry of Education; College of Environment and \\ Planning, Henan University, Kaifeng 475004, China \\ 5 Tea Research Institute, Guangdong Academy of Agricultural Sciences, Guangzhou 510650, China
}

\section{A RTICLE I NFO}

Article history:

Received December 31, 2019

Revised March 13, 2020

Accepted April 9, 2020

\section{Keywords:}

Soil

Herb residue vermicompost

Microbial biomass

Respiration

Enzyme activity

\begin{abstract}
A B S T R A C T
Herb residue vermicompost is thought to have high agriculture value, while its effects on soil microbial activities have not been fully understood. Here, soil microbial biomass, respiration and enzyme activities in soil planted with maize were compared among treatments amended with herb residue vermicompost at rates of $25,50,75$ and $100 \mathrm{~g} \mathrm{~kg}^{-1}$, chemical NPK fertilizer and no fertilizer (the control). Our results showed that soil microbial biomass carbon, respiration, and alkaline phosphatase, urease, and invertase activities were greater in soil amended with herb residue vermicompost than the unfertilized control $(P<0.05)$. Compared with chemical fertilizer, herb residue vermicompost increased soil urease and alkaline phosphatase activities at each application rate, promoted soil respiration and microbial biomass carbon at the application rates of 50,75 and $100 \mathrm{~g} \mathrm{~kg}^{-1}$, and increased soil inverse activity at the application rates of 75 and $100 \mathrm{~g} \mathrm{~kg}^{-1}$. In conclusion, herb residue vermicompost supported greater soil microbial biomass, respiration and enzyme activities than conventional NPK fertilizer, and the effect was larger when higher rates of herb residue vermicompost were added.
\end{abstract}

(c) Higher Education Press 2020

\section{Introduction}

Herb residue is a major form of solid organic waste, consisting of the leftover waste of plant material that has undergone decoction. Great amount of herb residue is produced worldwide, especially in Asian countries. For example, approxi-

\footnotetext{
* Corresponding authors

E-mail address: jundai@scau.edu.cn (J. Dai); zhangchi121@163.com (C. Zhang)
}

mately 1.5 million tons are generated annually in China (Wang et al., 2010). The traditional landfill treatment of herb residue causes serious environmental problems, such as underwater pollution and the release of odor, because herb residue is easy to decay and there is lots of drug residue (Zeng et al., 2016). Herb residue has been used to obtain biogas, however, the production of biogas requires relatively higher cost (Guo et al., 2013).

Vermicomposting is the non-thermophilic biodegradation of organic material arising from the interaction between earthworms and microorganisms, and it has been shown to be an 
efficient, low cost, and environmentally friendly technique for the disposal of organic wastes (Parthasarathi et al., 2008). The end product of this process, vermicompost, contains $\mathrm{N}, \mathrm{P}$, and $\mathrm{K}$ at high levels and has high cation exchange capacity and humic substances and low $\mathrm{C} / \mathrm{N}$ and $\mathrm{C} / \mathrm{P}$ ratios (Tejada et al., 2009; Carrión-Paladines et al., 2016). Being soil amends, vermicompost is preferable to traditional compost because of higher nutrient availability and humification degree (Tejada and Benitez, 2011). Vermicompost can increase soil nutrient availability (Roy et al., 2010), humic and fulvic acid carbon and carbon storage (Lashermes et al., 2009; Ngo et al., 2012), improve soil water-holding capacity and soil structure (Paradelo et al., 2009), reduce soil nutrient leaching (Jouquet et al., 2011), and augment the resistance of agrosystems to water stress (Doan et al., 2015). Although the effects of vermicompost on soil physical and chemical properties have been well-studied, its effects on soil microbial activities have not been fully understood.

Soil microorganisms are essential for regulating soil nutrient transformations and serve as significant indicators of soil quality. Some experiments had investigated how vermicompost affected soil microorganisms (Srivastava et al., 2012; Verma et al., 2014; Uz et al., 2016), yet their results were inconsistent. For examples, Maji et al. (2017) showed that vermicompost increased soil bacteria population, yet Yang et al. (2015) found that vermicompost decreased it. Sharma and Garg (2018) showed that vermicompost enhanced soil urease activity, in contrast to work by Romero et al. (2010) showing that vermicompost negligibly influenced soil urease activity after 7 days of application. Vermicompost used in those studies derived from different raw material, such as animal waste, sewage sludge and plant reside. Hence, the disparity and disagreement in vermicompost impact on soil microbial properties above may be associated with the properties of raw organic waste. Ghosh et al. (2018) showed that the characteristics of waste material governed the quality of resulting vermicompost. Ferreras et al. (2006) found that vermicompost from chicken manure affected soil microbial respiration more than that resulting from horse and rabbit manure at the same application rate. As an organic waste, herb residue is rich in cellulose and protein, so it may be suitable for use in vermicomposting to obtain vermicompost of high agronomic value. Singh and Suthar (2012) showed that there was great population of fungi, bacteria and actinomycete in herb residue vermicompost which may strongly influence soil indigenous microbial community. Therefore, information on the effects of herb residue verimcompost on soil microbial activities is urgently needed. However, the effects of herb residue vermicompost on soil microbial activities remain relatively understudied. Furthermore, the important value of herb residue vermicompost in agriculture is to improve soil quality and substitute chemical fertilizer, while there is limited information about the comparison between herb residue vermicompost and chemical fertilizer on influencing soil microbial activities.

Therefore, we experimentally tested the effects of herb residue vermicompost with four application rates on microbial biomass and respiration and enzyme activities of soil cultivated with maize plants in a pot experiment, and compared these with those from four chemical fertilizer treatments, which have equivalent $\mathrm{N}, \mathrm{P}$ and $\mathrm{K}$ amounts to those of the four herb residue vermicompost treatments. We supposed that 1) herb residue vermicompost at each application rate could improve soil microbial activities because of great microbial population and nutrient availability in vermicompost, and the highest application rate benefited soil microorganisms the most; 2) herb residue vermicompost affected soil microbial activities more than chemical fertilizer at each application rate because herb residue vermicompost could provide great diversity of substrates for soil microorganisms.

\section{Methods}

\subsection{Herb residue vermicompost and soil preparation}

Mixed herb residue containing various kinds of plant species was obtained from the Baihe Pharmaceutical factory, which produces various Chinese medicines, and then air-dried and cut-up to pass through a 5-mm sieve. Total C, N, P and K in the mixed herb residue were $305,31,4.0$ and $6.5 \mathrm{~g} \mathrm{~kg}^{-1}$, separately. Vermicomposting was carried out in plastic pot $(60 \mathrm{~cm} \times 52 \mathrm{~cm} \times 38 \mathrm{~cm}) .3 \mathrm{~kg}$ of herb residue was placed into plastic pot. The room temperature was kept at approximately $25^{\circ} \mathrm{C}$. The moisture content of herb residue was maintained at approximately 50\%. 300 individuals of earthworm Eisenia fetida (Goswami et al., 2017) were inoculated into herb residue. Herb residue vermicompost was obtained after 1 month. Table 1 showed $\mathrm{pH}$, carbon, and nutrient contents of herb residue vermicompost.

Soil was collected from the South China Agricultural University, Guangzhou, China $\left(23^{\circ} 8^{\prime} \mathrm{N}, 113^{\circ} 15^{\prime} \mathrm{E}\right)$, where a tropical ocean monsoon climate prevails with an annual average of $1780 \mathrm{~h}$ of total sunshine. The soil is latosolic red soil, and soil $\mathrm{pH}$, carbon, and nutrient contents are also shown in Table 1.

Table 1 Chemical properties of the experimental soil and herb residue vermicompost.

\begin{tabular}{lcccccccc}
\hline & $\mathrm{pH}$ & $\begin{array}{c}\text { Organic C } \\
\left(\mathrm{g} \mathrm{kg}^{-1}\right)\end{array}$ & $\begin{array}{c}\text { Total N } \\
\left(\mathrm{g} \mathrm{kg}^{-1}\right)\end{array}$ & $\begin{array}{c}\text { Total P } \\
\left(\mathrm{g} \mathrm{kg}^{-1}\right)\end{array}$ & $\begin{array}{c}\text { Total K } \\
\left(\mathrm{g} \mathrm{kg}^{-1}\right)\end{array}$ & $\begin{array}{c}\text { Available N } \\
\left(\mathrm{mg} \mathrm{kg}^{-1}\right)\end{array}$ & $\begin{array}{c}\text { Available P } \\
\left(\mathrm{mg} \mathrm{kg}^{-1}\right)\end{array}$ & $\begin{array}{c}\text { Available K } \\
\left(\mathrm{mg} \mathrm{kg}^{-1}\right)\end{array}$ \\
\hline $\begin{array}{l}\text { Soil } \\
\text { Herb residue }\end{array}$ & 5.35 & 6.66 & 0.25 & 0.267 & 3.63 & 58.96 & 0.98 & 77.65 \\
vermicompost & 7.02 & 265 & 21.15 & 2.04 & 6.67 & 2153 & 283 & 3016 \\
\hline
\end{tabular}




\subsection{Experimental design}

For this experiment, $3 \mathrm{~kg}$ of homogenized field dry soil was added to plastic pot that had an outer diameter of $50 \mathrm{~cm}$ and a height of $16 \mathrm{~cm}$. Nine treatments were established in the study: the application of herb residue vermicompost at 25, 50, 75, $100 \mathrm{~g}$ dry matter per $\mathrm{kg}$ dry soil in four separate treatments, labeling as HRV1, HRV2, HRV3 and HRV4, separately; the application of chemical fertilizer (mixture of urea, potassium dihydrogen phosphate and potassium chloride) at 1.55, 3.10, 4.65, $6.20 \mathrm{~g}$ per kg dry soil in another four treatments, labeling as CF1, CF2, CF3 and CF4, separately. Importantly, the total amount of $\mathrm{N}, \mathrm{P}$ and $\mathrm{K}$ in each of the four chemical fertilizer treatments was equivalent to those of the four herb residue vermicompost treatments. Furthermore, non-amended soil served as the control (i.e., the ninth treatment, CK). The experiment had four replicates per treatment.

One maize plant (Zea mays-Fengtian1) was planted in each pot by sowing five seeds and thinning them. Plants were then placed in a greenhouse for 60 days. During this period, soil moisture was adjusted by weight every 3 days. After the 60 day period, the soil of each pot was collected, mixed, and sieved to determine soil microbial biomass, respiration and enzyme activities.

\subsection{Measurements}

Organic $\mathrm{C}$ in soil and herb residue vermicompost was determined using a dichromate oxidation method (Walkley and Black, 1934). The total $\mathrm{N}$ in soil was quantified with the Kjeldahl digestion method (Mungai et al., 2005), and total $P$ and $\mathrm{K}$ values were respectively obtained with the molybdenum-blue colorimetry method and flame photometry method after digestion by $\mathrm{HF}-\mathrm{HClO}_{4}$ (Jackson, 1958). The total $\mathrm{N}, \mathrm{P}$, and $\mathrm{K}$ values in herb residue vermicompost were determined by the Kjeldahl method, the vanadomolybdophosphoric method, and flame photometry, respectively, after digesting with $\mathrm{H}_{2} \mathrm{SO}_{4}-\mathrm{H}_{2} \mathrm{O}_{2}$ (Xu et al., 2015). The available $\mathrm{N}, \mathrm{P}$ and $\mathrm{K}$ in soil and in herb residue vermicompost were determined by the alkali hydrolysable method, the $\mathrm{NH}_{4} \mathrm{~F}-\mathrm{HCl}$ extraction method and the $\mathrm{NH}_{4} \mathrm{OAc}$ extraction method (Jalali, 2006, Singh and Reddy, 2011, Li et al., 2015). $\mathrm{pH}\left(\mathrm{H}_{2} \mathrm{O}\right)$ was measured with a $\mathrm{pH}$ meter. Each parameter was measured by three repetitions.

The microbial biomass of $\mathrm{C}$ and $\mathrm{N}$ were determined according to the chloroform fumigation extraction procedure using a conversion factor of $K_{\mathrm{EC}}=0.38$ and $K_{\mathrm{EN}}=0.54$, respectively (Scalise et al., 2015). Soil respiration was determined using alkali-trapping technique (Mizuta et al., 2015). The respiratory quotient was then calculated as the amount of $\mathrm{CO}_{2}-\mathrm{C}$ produced per unit of microbial biomass $\mathrm{C}$ (Thirukkumaran and Parkinson, 2000). The activities of four soil extracellular enzymes, namely, invertase, urease, alkaline phosphatase, and acid phosphatase, were quantified by colorimetric methods ( $\mathrm{Li}$ et al., 2009), using the substrates of sucrose, urea, and p-nitrophenyl phosphate. Each parameter was measured by three repetitions.

\subsection{Statistical analyses}

To examine the effects of herb residue vermicompost on soil microbial biomass, respiration and enzyme activities and to compare them with those of chemical fertilizer, one-way ANOVA, t-test, regression analysis, Pearson correlation analysis and principal components analysis (PCA) were performed. Means were compared by Duncan's test. Statistical analyses were performed using SPSS v16.0 in addition to the $\mathrm{R}$ platform (ade4 library).

\section{Results}

Herb residue vermicompost led to an increase of $182 \%-389 \%$ in soil microbial biomass $\mathrm{C}$ relative to the control $(P<0.05$, CK), which increased monotonically with application rate (Fig. 1A). Compared with chemical fertilizer, herb residue vermicompost increased soil microbial biomass $\mathrm{C}$ by $68 \%-$ $532 \%$ at $50-100 \mathrm{~g} \mathrm{~kg}^{-1}$ application rates (Fig. $1 \mathrm{~A}^{\prime}, P<0.05$ ). Herb residue vermicompost increased soil microbial biomass $\mathrm{N}$ by $132 \%$ over CK and by $395 \%$ over chemical fertilizer at

Table 2 Experimental design.

\begin{tabular}{lrccc}
\hline Treatments & \multicolumn{3}{c}{ Application rate $\left(\mathrm{g} \mathrm{kg}^{-1}\right.$ soil) } \\
\cline { 2 - 5 } & $\mathrm{HRV}$ & $\mathrm{CO}\left(\mathrm{NH}_{2}\right)_{2}$ & $\mathrm{KH}_{2} \mathrm{PO}_{4}$ & $\mathrm{KCl}$ \\
\hline CK & 0 & 0 & 0 & 0 \\
HRV1 & 25 & 0 & 0 & 0 \\
HRV2 & 50 & 0 & 0 & 0 \\
HRV3 & 75 & 0 & 0 & 0 \\
HRV4 & 100 & 0 & 0 & 0 \\
CF1 & 0 & 1.13 & 0.22 & 0.2 \\
CF2 & 0 & 2.26 & 0.44 & 0.4 \\
CF3 & 0 & 3.39 & 0.66 & 0.6 \\
CF4 & 0 & 4.52 & 0.88 & 0.8 \\
\hline
\end{tabular}

HRV1, HRV2, HRV3 and HRV4: herb residue vermicompost treatment with 25, 50, 75 and $100 \mathrm{~g} \mathrm{~kg}^{-1}$ application rates, separately. CF1, CF2, CF3 and CF4: chemical fertilizer treatment with $1.55,3.10,4.65$ and $6.20 \mathrm{~g} \mathrm{~kg}^{-1}$ application rates, separately. The total amount of N, P and K in each of the four chemical fertilizer treatments was equivalent to those of the four herb residue vermicompost treatments. 

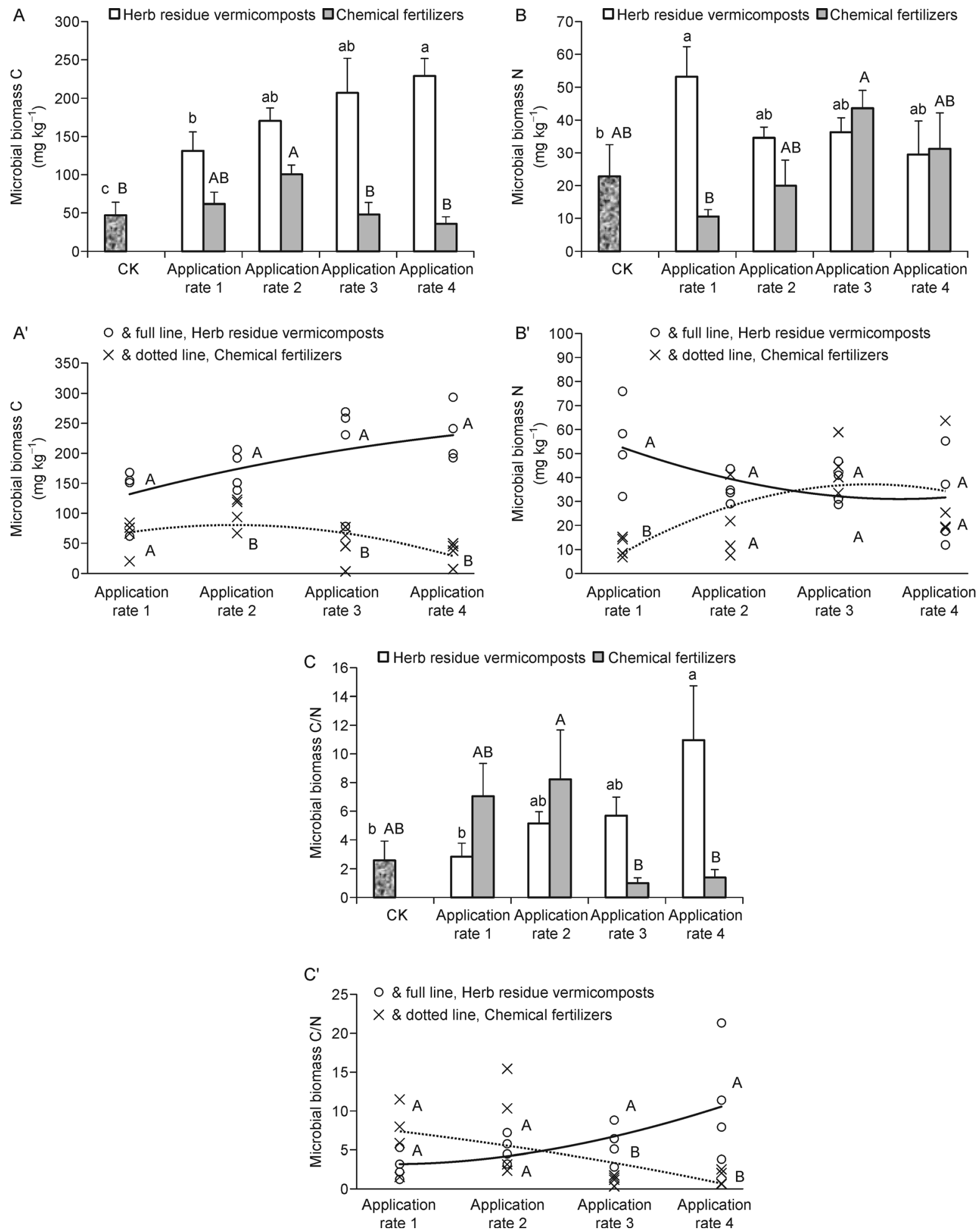

Fig. 1 Soil microbial biomass $C\left(A, A^{\prime}\right)$, microbial biomass $N\left(B, B^{\prime}\right)$, and microbial biomass $C / N\left(C, C^{\prime}\right)$ in the herb residue vermicompost and chemical fertilizer treatments. Mean values of these indicators were showed by histogram at Fig. 1A-Fig. 1C, and curve correlation between these indicators and input rates were shown at Fig. 1A'-Fig. 1C'. Application rate 1, 2, 3 and 4: herb residue vermicompost was applied at 25, 50,75 and $100 \mathrm{~g} \mathrm{~kg}^{-1}$ and chemical fertilizer was applied at $1.55,3.10,4.65$ and $6.20 \mathrm{~g} \mathrm{~kg}^{-1}$, separately. The total amount of $\mathrm{N}, \mathrm{P}$ and $\mathrm{K}$ in each of the four chemical fertilizer treatments was equivalent to those of the four herb residue vermicompost treatments. At Fig. 1A-Fig. 1C, mean values are shown + SEM $(n=4)$, and the SEM is indicated by error bars. Different lower-case letters indicate significant differences at $P$ $=0.05$ among herb residue vermicompost treatments, and capital letters indicate significant differences at $P=0.05$ among chemical fertilizer treatments. At Fig. 1A'-Fig. 1C', different capital letters indicate significant differences at $P=0.05$ between herb residue vermicompost and chemical fertilizer treatments. 
$25 \mathrm{~g} \mathrm{~kg}^{-1}$ application rate $(P<0.05)$ and did not significantly change it when compared to either $\mathrm{CK}$ or chemical fertilizer (Fig. 1B, B') at other application rates. Furthermore, herb residue vermicompost increased microbial biomass $\mathrm{C} / \mathrm{N}$ compared to $\mathrm{CK}$ at the $100 \mathrm{~g} \mathrm{~kg}^{-1}$ application rate and compared to chemical fertilizer at 75 and $100 \mathrm{~g} \mathrm{~kg}^{-1}$ application rate $(P<0.05)$ and did not significantly it at other application rates (Fig. 1C, $C^{\prime}$ ).

Compared to $\mathrm{CK}$, herb residue vermicompost increased soil respiration with higher application rates (Fig. 2A). Compared to chemical fertilizer, herb residue vermicompost did not significantly change soil respiration at $25 \mathrm{~g} \mathrm{~kg}^{-1}$ application rate but increased it at other application rates $\left(P<0.05\right.$, Fig. $\left.2 A^{\prime}\right)$. Soil respiratory quotient did not significantly change among the herb residue vermicompost, chemical fertilizer, and CK treatments (Fig. 2B, B').

Compared to $\mathrm{CK}$, herb residue vermicompost decreased soil acid phosphatase activity by $27 \%$ at $25 \mathrm{~g} \mathrm{~kg}^{-1}$ application rate $(P<0.05)$ and did not significantly affect it at other application rates (Fig. 3A). When compared to chemical fertilizer, herb residue vermicompost decreased soil acid phosphatase activity at $25 \mathrm{~g} \mathrm{~kg}^{-1}$ and $50 \mathrm{~g} \mathrm{~kg}^{-1}$ application rates and increased it at $100 \mathrm{~g} \mathrm{~kg}^{-1}$ application rate $(P<0.05$, Fig. $\left.3 A^{\prime}\right)$. Herb residue vermicompost increased soil alkaline phosphatase activity by $107 \%-123 \%$ over CK and even more so over chemical fertilizer, by $355 \%-477 \%(P<0.05$, Fig. 3B, $\left.B^{\prime}\right)$. With respect to the soil urease activity, herb residue vermicompost increased it by $331 \%-923 \%$ over CK $(P<0.05)$ and this effect was more pronounced with higher application rates (Fig. $3 \mathrm{C}$ ). When compared to chemical fertilizer, herb residue vermicompost increased it by $43 \%-193 \%$ across all application rates $(P<0.05$, Fig. 3C'). Herb residue vermicompost increased soil invertase activity relative to $\mathrm{CK}(P<0.05)$ and this effect strengthened with application rate (Fig. 3D). When compared to chemical fertilizer, herb residue vermicompost increased soil invertase activity at $75 \mathrm{~g} \mathrm{~kg}^{-1}$ and $100 \mathrm{~g}$ $\mathrm{kg}^{-1}$ application rates by $177 \%$ and $473 \% \quad(P<0.05)$, respectively, but did not significantly change it at other application rates (Fig. 3D').

Pearson correlation analysis revealed that soil microbial biomass $C$ was significantly positively correlated with all determined indicators except microbial biomass $\mathrm{N}$ (Table 3 ). Microbial biomass $\mathrm{N}$ was only negatively correlated with microbial biomass $\mathrm{C} / \mathrm{N}$. Soil respiration was positively correlated with all determined indicators except microbial biomass $\mathrm{N}$ and respiratory quotient. Acid phosphatase activity was positively correlated with microbial biomass $C$ and $C / N$, invertase activity and respiration, and alkaline phosphatase activity was positively correlated with microbial biomass C, urease and invertase activities and respiration. Invertase
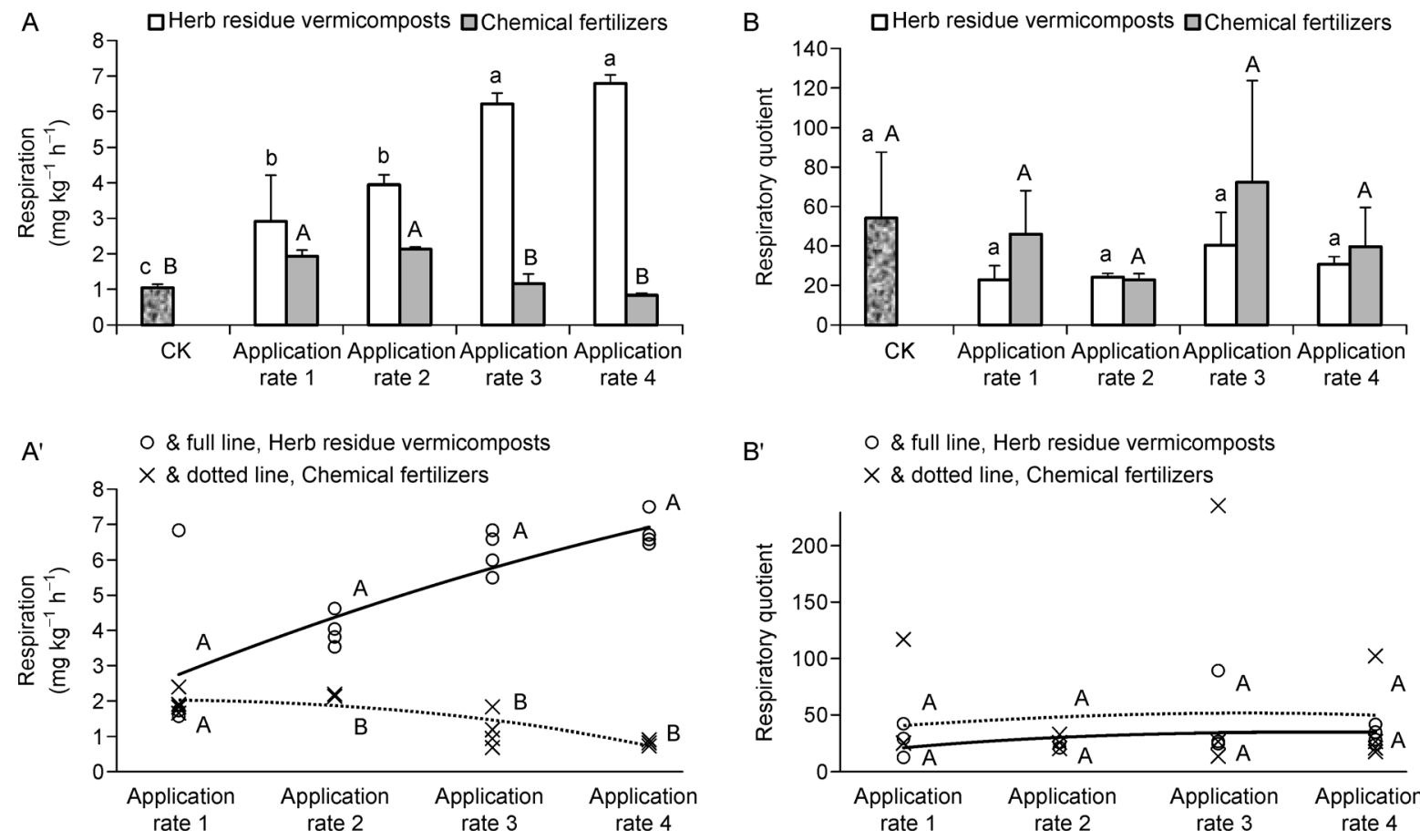

B' $\quad \circ \&$ full line, Herb residue vermicomposts

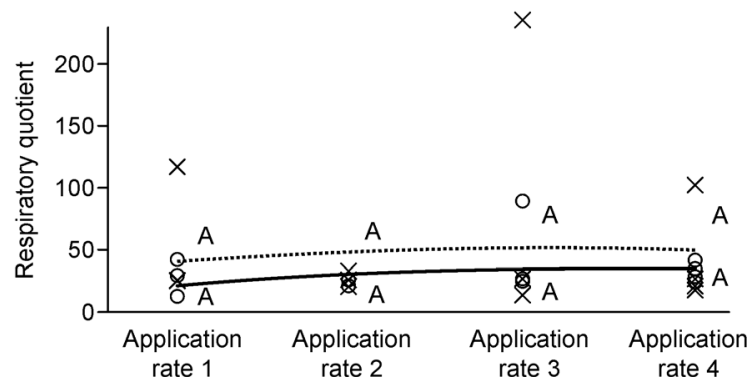

Fig. 2 Respiration $\left(A, A^{\prime}\right)$ and respiratory quotient $\left(B, B^{\prime}\right)$ in herb residue vermicompost and chemical fertilizer treatments. Mean values of these indicators were shown by histogram at Fig. 2A-Fig. 2B, and curve correlation between these indicators and input rates were shown at Fig. 2A'-Fig. 2B'. Application rate 1, 2, 3 and 4: herb residue vermicompost was applied at 25, 50, 75 and $100 \mathrm{~g} \mathrm{~kg}^{-1}$ and chemical fertilizer was applied at $1.55,3.10,4.64$ and $6.20 \mathrm{~g} \mathrm{~kg}^{-1}$, separately. The total amount of $\mathrm{N}, \mathrm{P}$ and $\mathrm{K}$ in each of the four chemical fertilizer treatments was equivalent to those of the four herb residue vermicompost treatments. At Fig. 2A-Fig. 2B, mean values are shown + SEM ( $n=4)$, and the SEM is indicated by error bars. Different lower-case letters indicate significant differences at $P=0.05$ among herb residue vermicompost treatments, and capital letters indicate significant differences at $P=0.05$ among chemical fertilizer treatments. At Fig. 2A'-Fig. 2B', different capital letters indicate significant differences at $P=0.05$ between herb residue vermicompost and chemical fertilizer treatments. 

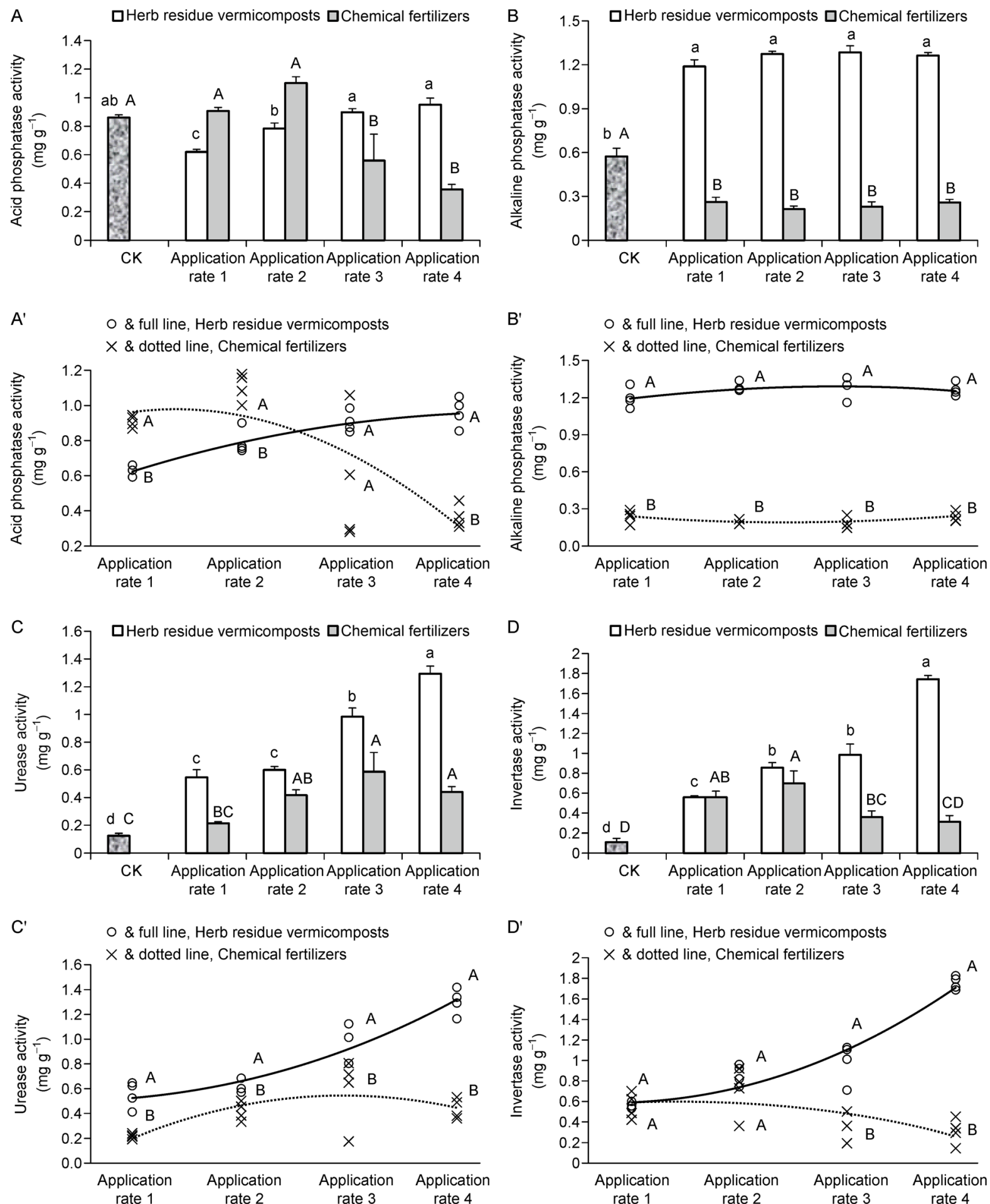

$D^{\prime}$

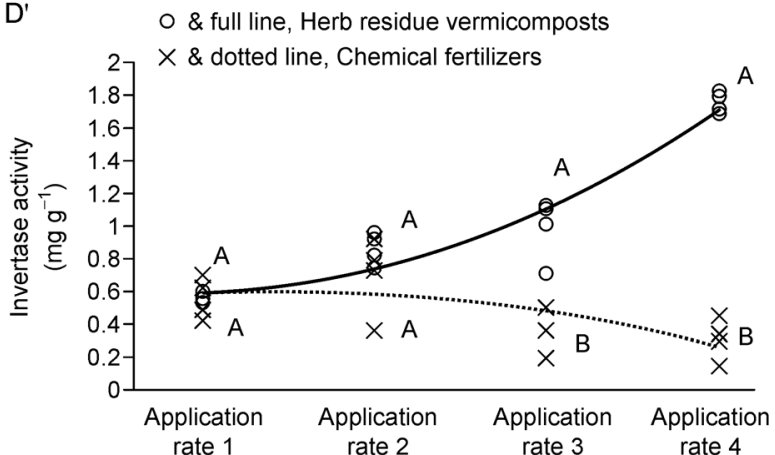

Fig. 3 Acid phosphatase activity $\left(A, A^{\prime}\right)$, alkaline phosphatase activity $\left(B, B^{\prime}\right)$, urease activity $\left(C, C^{\prime}\right)$, and invertase activity ( $D$, $\left.D^{\prime}\right)$ in the herb residue vermicompost and chemical fertilizer treatments. Mean values of these indicators were shown by histogram at Fig. 3A-Fig. 3D, and curve correlation between these indicators and input rates were shown at Fig. 3A'-Fig. 3D'. Application rate 1, 2, 3 and 4: herb residue vermicompost was applied at 25,50,75 and $100 \mathrm{~g} \mathrm{~kg}^{-1}$ and chemical fertilizer was applied at 1.55, 3.10, 4.65 and 6.20 g kg ${ }^{-1}$, separately. The total amount of N, P and K in each of the four chemical fertilizer treatments was equivalent to those of the four herb residue vermicompost treatments. At Fig. 3A-Fig. 3D, mean values are shown + SEM $(n=4)$; the SEM is indicated by error bars. Different lower-case letters indicate significant differences at $P=0.05$ among herb residue vermicompost treatments, and capital letters indicate significant differences at $P=0.05$ among chemical fertilizer treatments. At Fig. 3A'-Fig. 3D', different capital letters indicate significant differences at $P=0.05$ between herb residue vermicompost and chemical fertilizer treatments. 
Table 3 Correlation of soil microbial biomass, enzyme activities and respiration in herb residue vermicompost and chemical fertilizer treatments.

\begin{tabular}{|c|c|c|c|c|c|c|c|c|c|}
\hline & $\begin{array}{l}\text { Microbial } \\
\text { biomass } \mathrm{N}\end{array}$ & $\begin{array}{l}\text { Microbial } \\
\text { biomass C }\end{array}$ & $\begin{array}{l}\text { Microbial } \\
\text { biomass } \mathrm{C} / \mathrm{N}\end{array}$ & $\begin{array}{l}\text { Acid } \\
\text { phosphatase }\end{array}$ & $\begin{array}{l}\text { Alkaline } \\
\text { phosphatase }\end{array}$ & Urease & Invertase & Respiration & $\begin{array}{l}\text { Respiratory } \\
\text { quotient }\end{array}$ \\
\hline $\begin{array}{l}\text { Microbial } \\
\text { biomass } \mathrm{N}\end{array}$ & 1 & 0.167 & $-0.517^{\star *}$ & -0.322 & 0.319 & 0.214 & -0.014 & 0.024 & -0.218 \\
\hline $\begin{array}{l}\text { Microbial } \\
\text { biomass C }\end{array}$ & & 1 & $0.536^{\star *}$ & $0.361^{*}$ & $0.734^{* *}$ & $0.717^{* *}$ & $0.738^{* *}$ & $0.811^{* *}$ & $-0.422^{*}$ \\
\hline $\begin{array}{l}\text { Microbial } \\
\text { biomass } \mathrm{C} / \mathrm{N}\end{array}$ & & & 1 & $0.471^{* *}$ & 0.181 & $0.354^{*}$ & $0.497^{\star *}$ & $0.437^{\star \star}$ & -0.292 \\
\hline $\begin{array}{l}\text { Acid } \\
\text { phosphatase }\end{array}$ & & & & 1 & 0.147 & 0.171 & $0.436^{\star *}$ & $0.342^{*}$ & -0.260 \\
\hline $\begin{array}{l}\text { Alkaline } \\
\text { phosphatase }\end{array}$ & & & & & 1 & $0.624^{* *}$ & $0.606^{\star *}$ & $0.757^{* *}$ & -0.131 \\
\hline Urease & & & & & & 1 & $0.844^{* \star}$ & $0.821^{* *}$ & -0.205 \\
\hline Invertase & & & & & & & 1 & $0.833^{* *}$ & -0.177 \\
\hline Respiration & & & & & & & & 1 & -0.092 \\
\hline $\begin{array}{l}\text { Respiratory } \\
\text { quotient }\end{array}$ & & & & & & & & & 1 \\
\hline
\end{tabular}

activity was positively correlated with microbial biomass $C$ and $\mathrm{C} / \mathrm{N}$, respiration and all enzyme activities. Similarly, urease activity was positively correlated with microbial biomass $\mathrm{C}$ and $\mathrm{C} / \mathrm{N}$, respiration and all enzyme activities except acid phosphatase activity.

From the PCA analysis, along axis 1 (50.2\% variance explained) those treatments with high soil respiration, microbial biomass $\mathrm{C}$, invertase activity, urease activity and alkaline phosphatase activity were opposed to treatments with a high respiratory quotient. PCA axis 2 (20.2\% variance explained) contrasted treatments with high soil acid phosphatase activity and soil microbial biomass $\mathrm{C} / \mathrm{N}$ to those treatments with high microbial biomass $\mathrm{N}$. Herb residue vermicompost was projected to the left side of axis 1 , whereas chemical fertilizer and $\mathrm{CK}$ were projected to its right side. High application rates of herb residue vermicompost were associated with high soil respiration, soil microbial biomass $\mathrm{C}$, invertase and urease activities.

\section{Discussion}

Our results showed that herb residue vermicompost improved soil microbial biomass $\mathrm{C}$, respiration, and some enzyme activities (Fig. 4). Enhanced these soil microbial indicators following greater application rates strongly indicated the benefit of herb residue vermicompost for soil microorganisms and their functioning. This result was consistent with our assumption. Compared with chemical fertilizer, herb residue vermicompost has been shown to provide a great diversity of carbon and nutrient substrates for soil microorganisms (Arancon et al., 2006). This may be the reason that herb residue vermicompost increased soil alkaline phosphatase and urease activities at 25 and $50 \mathrm{~g} \mathrm{~kg}^{-1}$ application rates and promoted more microbial indicators, such as soil microbial biomass $\mathrm{C}$, respiration and inverse activity, at 75 and $100 \mathrm{~g} \mathrm{~kg}^{-1}$ application rates. High soil microbial activities could accelerate soil nutrient cycling and contribute to the growth of plants (Lupwayi et al., 2012). At 75 and $100 \mathrm{~g} \mathrm{~kg}^{-1}$ application rates, the biomass of maize in herb residue vermicompost treatments was significantly higher than that in chemical fertilizer treatments (Li et al., 2013). Generally, these results suggested that herb residue vermicompost has the potential to be used as an alternative to chemical fertilizer for improving soil microbial activities, and the application rates with 75 and $100 \mathrm{~g} \mathrm{~kg}^{-1}$ were better. This result was not consistent with our hypothesis that herb residue vermicompost increased soil microbial activities more than chemical fertilizers at each application rate. No significant difference of some soil microbial indicators between herb residue vermicompost and chemical fertilizer treatments at 25 and $50 \mathrm{~g} \mathrm{~kg}^{-1}$ application rates may be due to the initial condition of soil nutrients. Our studied soil was deficient in nutrients, especially $\mathrm{N}$. Thus, at low applicate rate, either organic or inorganic nutrient inputs was useful for improving poor soil nutrient conditions, leading to similar increase of some soil microbial indicators between herb residue vermicompost and chemical fertilizer treatments. Furthermore, with the increase of application rate, the change trends of soil microbial properties in chemical fertilizer treatments were not consistent with that in herb residue vermicompost treatments. In chemical fertilizer treatments, some microbial properties, such as microbial biomass $\mathrm{C}$, respiration, acid phosphatase and invertase activities, significantly decreased in soils with high application rates compared to that with low application rates. This suggested that there was a critical load of chemical fertilizer for soils. On the one hand, chemical fertilizer has positive effects on soil microorganisms due to nutrient supply. On the other hand, chemical fertilizer has negative effects on it attributing to osmotic effect, soil acidity and aluminum toxicity. With the increase of application rate, the negative effects of chemical fertilizer may overpower its positive effects (Lupwayi et al., 2011, 2012). 


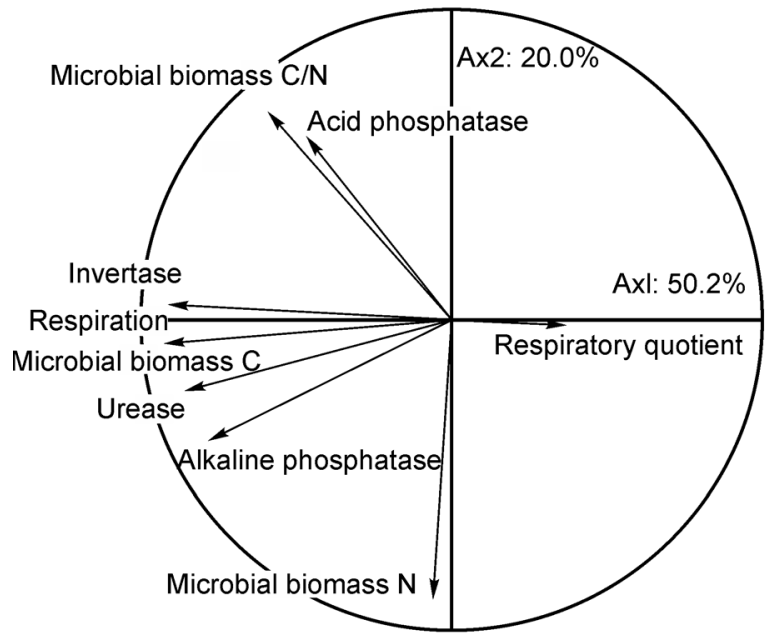

A

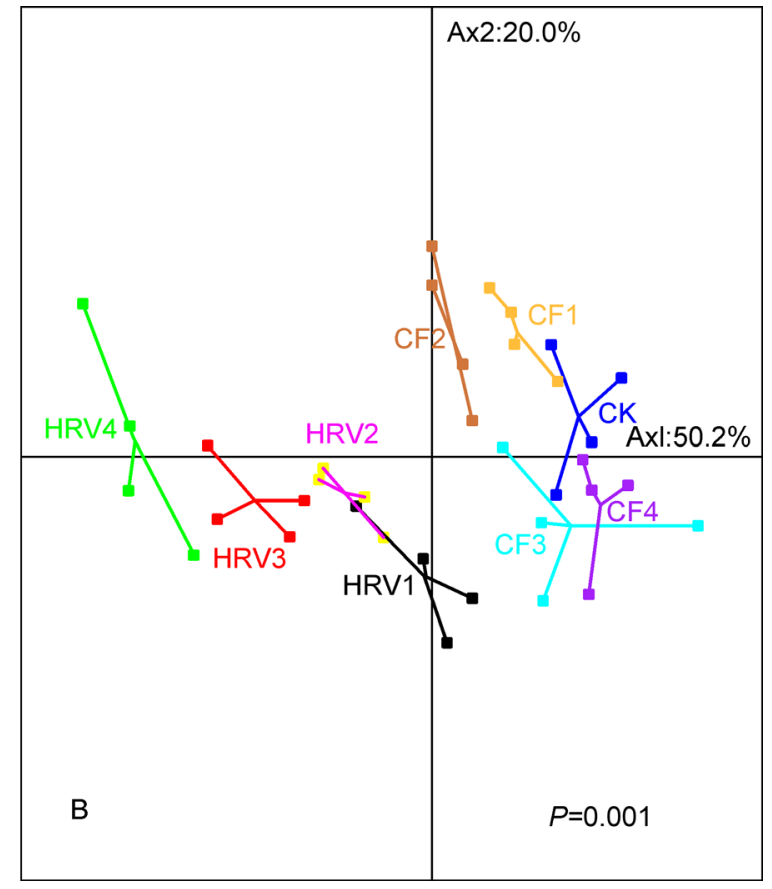

Fig. 4 Principal components analysis of soil microbial activities in the treatments, showing $(A)$ their correlations and (B) the projection of experimental points according herb residue vermicomposts (HRV), chemical fertilizers (CF), and the control (CK). HRV1, HRV2, HRV3 and HRV4: herb residue vermicompost treatment with $25,50,75$ and $100 \mathrm{~g} \mathrm{~kg}^{-1}$ application rate, separately. CF1, CF2, CF3 and CF4: chemical fertilizer treatment with $1.55,3.10,4.65$ and $6.20 \mathrm{~g} \mathrm{~kg}^{-1}$ application rate, separately. The total amount of $\mathrm{N}, \mathrm{P}$ and $\mathrm{K}$ in each of the four chemical fertilizer treatments was equivalent to those of the four herb residue vermicompost treatments

Interestingly, the response trend of soil microbial biomass $\mathrm{N}$ to the treatments did not match that of soil microbial biomass C in our study. This was inconsistent with previous studies which suggested soil microbial biomass $\mathrm{C}$ and $\mathrm{N}$ were closely associated (Powlson et al., 1987). We also found that microbial biomass $\mathrm{C} / \mathrm{N}$ did not significantly change in the soils receiving $25-75 \mathrm{~g} \mathrm{~kg}^{-1}$ herb residue vermicompost application rates, but it did significantly increase at $100 \mathrm{~g} \mathrm{~kg}^{-1}$ herb residue vermicompost application rate. Zhu et al. (2018) showed that when nutrient availability changed in soil environments, soil microorganisms responded through changing their stoichiometry to maintain an elemental stoichiometric balance between resources and their microbial requirements. Heuck et al. (2015) showed that labile C addition could cause high microbial $\mathrm{C}$ concentration and inorganic $\mathrm{N}$ addition could cause high microbial $\mathrm{N}$ concentration. From our study, we infer there may be a threshold of herb residue vermicompost input to elicit a change in soil microbial biomass $\mathrm{C} / \mathrm{N}$. When low levels of organic material are applied, soil microorganisms may self-organize and thereby maintain the $\mathrm{C} / \mathrm{N}$ equilibrium inside their cellular structures. But when microorganisms acquire more extraneous organic material supplied from herb residue vermicompost, their community structure may change rapidly, such as shifting from $r$ - to Kstrategists which elevates their decomposition ability (Kalbitz et al., 2000), consequently leading to a changed soil microbial biomass $\mathrm{C} / \mathrm{N}$. Furthermore, high $\mathrm{N}$ absorption of maize plants at high herb residue vermicompost application rates (data not shown) may also explain the changed microbial stoichiometry, since it could alter the stoichiometry of available $\mathrm{C}$ and $\mathrm{N}$ in soil (Raynaud et al., 2006).

Soil respiration was regulated by two factors: respiratory quotient and total biomass of soil microorganisms. We postulated that herb residue vermicompost would increase respiratory quotient by supplying soil microorganisms with available $\mathrm{C}$ and nutrients, because numerous microorganisms in soils are dormant and are awaiting suitable conditions to become active (Lavelle et al., 1992). To our surprise, respiratory quotient was not significantly influenced by herb residue vermicompost. That is, herb residue vermicompost increased soil respiration only by augmenting the total biomass of soil microorganisms. Soil respiratory quotient is not only affected by the individual activity of soil microorganisms but also by their community structure (Zhou et al., 2017). Yang et al. (2015) reported that vermicompost caused soil fungi to increase and soil bacteria to decrease. Our result of increased soil microbial biomass $\mathrm{C} / \mathrm{N}$ with the increase of application rates in the herb residue vermicompost treatments also suggested that the composition of soil microorganisms shifted toward fungal dominance, because the $\mathrm{C} / \mathrm{N}$ in bacteria is approximately 5 while that of fungi is 10 (Heuck et al., 2015). Compared with bacteria, fungi has high $\mathrm{C}$ assimilation efficiency $(30 \%-40 \%$ in fungi and $5 \%-10 \%$ in bacteria; Sakamoto and Oba, 1994) and a lower turnover rate (170 
days in fungi vs. just 4 days in bacteria; Bååth, 2001; Rousk and Bååth, 2011). In other words, the change of microbial community structure toward fungi may prevent an increase of soil respiratory quotient incurred from available nutrient input in herb residue vermicompost treatments. Furthermore, our results showed that the soil fungi-to-bacteria ratio determined by the plating method tended to increase but did not reach a significant level (data not listed). We consider the plating method do not fully describe all microbial communities, since a vast majority of soil microorganisms cannot be cultured.

Herb residue vermicompost increased soil invertase and urease activities, maybe because of high enzymatic- $\mathrm{C}$ and $\mathrm{N}$ substrates and enzymes in herb residue vermicompost. This result was consistent with previous studies (Pramanik et al., 2010; Tejada et al., 2010). Furthermore, previous studies showed that vermicompost increased soil phosphatase activity (Wang et al., 2018), because 1) vermicompost had large amounts of acid and alkaline phosphatase due to high microbial activity in vermicompost and earthworm-gut secretion (Satchell and Martin, 1984); 2) vermicompost could promote indigenous soil microorganisms and increase phosphatase secretion by creating a favorable environment (Zuo et al., 2018). So, we postulated that herb residue vermicompost increased soil acid and alkaline phosphatase activity with the increase of application rate. However, our results showed that herb residue vermicompost increased soil alkaline phosphatase activity at each application rate, while it decreased soil acid phosphatase activity at the $25 \mathrm{~g} \mathrm{~kg}^{-1}$ application rate and did not significantly affect soil acid phosphatase activity at other application rates. This result may be explained by soil $\mathrm{pH}$, because soil acid and alkaline phosphatase are pH-dependent enzymes (Villar et al., 2017) and alkaline phosphatase can remain more active over neutral $\mathrm{pH}$ range than acid phosphatase (Pramanik et al., 2007). When neutral herb residue vermicompost was applied to acidic soils in our study, soil $\mathrm{pH}$ was far from the suitable $\mathrm{pH}$ of acid phosphatase.

\section{Conclusion}

Our study suggested that vermicomposting herb residue to be as organic fertilizer offered a good way for herb residue disposal. The increase of 3-14 times in soil microbial biomass $C$, respiration, urease and invertase activities under the application of $100 \mathrm{~g} \mathrm{~kg}^{-1}$ herb residue vermicompost indicated the wonderful effect of this application rate on soil microbial activities. This study provides important insights into the role of herb residue vermicompost in regulating soil microbial activities.

\section{Acknowledgments}

This work was supported by the Natural Science Foundation of Shandong Province, China (ZR201801300002; ZR2016DM17; ZR2018ZB0523; ZR2019PD004), the Natural Science Foundation of China (31700447 and 41201305), Science and Technology
Fundamental Resources Investigation Program of China (2018FY100300), National Key Research and Development Program of China (2016YFD0201301 and 2016YFD0201200).

\section{References}

Arancon, N.Q., Edwards, C.A., Bierman, P., 2006. Influences of vermicomposts on field strawberries, Part 2. Effects on soil microbiological and chemical properties. Bioresource Technology 97, 831-840.

Bååth, E., 2001. Estimation of fungal growth rates in soil using ${ }^{14} \mathrm{C}$ acetate incorporation into ergosterol. Soil Biology \& Biochemistry 33, 2011-2018.

Carrión-Paladines, V., Fries, A., Gómez-Muñoz, B., García-Ruiz, R., 2016. Agrochemical characterization of vermicomposts produced from residues of Palo Santo (Bursera graveolens) essential oil extraction. Waste Management (New York, N.Y.) 58, 135-143.

Doan, T.T., Henry-des-Tureaux, T., Rumpel, C., Janeau, J.L., Jouquet, P., 2015. Impact of compost, vermicompost and biochar on soil fertility, maize yield and soil erosion in Northern Vietnam, a three year mesocosm experiment. Science of the Total Environment 514, 147-154.

Ferreras, L., Gomez, E., Toresani, S., Firpo, I., Rotondo, R., 2006. Effect of organic amendments on some physical, chemical and biological properties in a horticultural soil. Bioresource Technology 97, 635-640.

Ghosh, S., Goswami, A.J., Ghosh, G.K., Pramanik, P., 2018. Quantifying the relative role of phytase and phosphatase enzymes in phosphorus mineralization during vermicomposting of fibrous tea factory waste. Ecological Engineering 116, 97-103.

Goswami, L., Nath, A., Sutradhar, S., Bhattacharya, S.S., Kalamdhad, A., Vellingiri, K., Kim, K., 2017. Application of drum compost and vermicompost to improve soil health, growth, and yield parameters for tomato and cabbage plants. Journal of Environmental Management 200, 243-252.

Guo, F.Q., Dong, Y.P., Dong, L., Jing, Y., 2013. An innovative example of herb residues recycling by gasification in a fluidized bed. Waste Management (New York, N.Y.) 33, 825-832.

Heuck, C., Weig, A., Spohn, M., 2015. Soil microbial biomass C,N,P stoichiometry and microbial use of organic phosphorus. Soil Biology \& Biochemistry 85, 119-129.

Jackson, M.L., 1958. Soil Chemical Analysis. Prentice-Hall, Inc., Englewood Cliffs, NJ.

Jalali, M., 2006. Kinetics of non-exchangeable potassium release and availability in some calcareous soils of western Iran. Geoderma $135,63-71$.

Jouquet, E.P., Bloquel, E., Doan, T.T., Ricoy, M., Orange, D., Rumpel, C., Duc, T.T., 2011. Do compost and vermicompost improve macronutrient retention and plant growth in degraded tropical soils? Compost Science \& Utilization 19, 15-24.

Kalbitz, K., Solinger, S., Park, J.H., Michalzik, B., Matzner, E., 2000. Controls on the dynamics of dissolved organic matter in soils, A review. Soil Science 165, 277-304.

Lashermes, G., Nicolardot, B., Parnaudeau, V., Thuries, L., Chaussod, R., Guillotin, M.L., Lineres, M., Mary, B., Metzger, L., Morvan, 
T., Tricaud, A., Villette, C., Houot, S., 2009. Indicator of potential residual carbon in soils after exogenous organic matter application. European Journal of Soil Science 60, 297-310.

Lavelle, P., Melendez, G., Pashanasi, B., Schaefer, R., 1992. Nitrogen mineralization and reorganization in casts of the geophagous tropical earthworm Pontoscolex corethrurus (Glossoscolecidae). Biology and Fertility of Soils 14, 49-53.

Li, H., Cong, R., Ren, T., Li, X., Ma, C., Zheng, L., Zhang, Z., Lu, J., 2015. Yield response to $N$ fertilizer and optimum $N$ rate of winter oilseed rape under different soil indigenous $\mathrm{N}$ supplies. Field Crops Research 181, 52-59.

Li, J., Zhou, B., Zhang, C., Zhang, J., Xu, H., Yang, X., Chen, X., Dai, J., 2013. Effects of herb residue vermicompost on maize growth and soil fertility. Ying Yong Sheng Tai Xue Bao 24, 2651-2657 (In Chinese).

Li, Y., Rouland, C., Benedetti, M., Li, F., Pando, A., Lavelle, P., Dai, J., 2009. Microbial biomass, enzyme and mineralization activity in relation to soil organic $\mathrm{C}, \mathrm{N}$ and $\mathrm{P}$ turnover influenced by acid metal stress. Soil Biology \& Biochemistry 41, 969-977.

Lupwayi, N.Z., Clayton, G.W., O'Donovan, J.T., Grant, C.A., 2011. Soil microbial response to nitrogen rate and placement and barley seeding rate under no till. Agronomy Journal 103, 1064-1071.

Lupwayi, N.Z., Lafond, G.P., Ziadi, N., Grant, C.A., 2012. Soil microbial response to nitrogen fertilizer and tillage in barley and corn. Soil \& Tillage Research 118, 139-146.

Maji, D., Misra, P., Singh, S., Kalra, A., 2017. Humic acid rich vermicompost promotes plant growth by improving microbial community structure of soil as well as root nodulation and mycorrhizal colonization in the roots of Pisum sativum. Applied Soil Ecology 110, 97-108.

Mizuta, K., Taguchi, S., Sato, S., 2015. Soil aggregate formation and stability induced by starch and cellulose. Soil Biology \& Biochemistry $87,90-96$.

Mungai, N.W., Motavalli, P.P., Kremer, R.J., Nelson, K.A., 2005. Spatial variation of soil enzyme activities and microbial functional diversity in temperate alley cropping systems. Biology and Fertility of Soils 42, 129-136.

Ngo, P., Rumpel, C., Doan, T., Jouquet, P., 2012. The effect of earthworms on carbon storage and soil organic matter composition in tropical soil amended with compost and vermicompost. Soil Biology \& Biochemistry 50, 214-220.

Paradelo, R., Moldes, A.B., Barral, M.T., 2009. Amelioration of the physical properties of slate processing fines using grape marc compost and vermicompost. Soil Science Society of America Journal 73, 1251-1260.

Parthasarathi, K., Balamurugan, M., Ranganathan, L.S., 2008. Influence of vermicompost on the physico-chemical and biological properties in different types of soil along with yield and quality of the pulse crop-black gram. Journal of Environmental Health Science \& Engineering 5, 51-58.

Powlson, D.S., Prookes, P.C., Christensen, B.T., 1987. Measurement of soil microbial biomass provides an early indication of changes in total soil organic matter due to straw incorporation. Soil Biology \& Biochemistry 19, 159-164.

Pramanik, P., Ghosh, G.K., Chung, Y.R., 2010. Changes in nutrient content, enzymatic activities and microbial properties of lateritic soil due to application of different vermicomposts, A comparative study of ergosterol and chitin to determine fungal biomass in soil. Soil Use and Management 26, 508-515.

Pramanik, P., Ghosh, G.K., Ghosal, P.K., Banik, P., 2007. Changes in organic- $\mathrm{C}, \mathrm{N}, \mathrm{P}$ and $\mathrm{K}$ and enzyme activities in vermicompost of biodegradable organic wastes under liming and microbial inoculants. Bioresource Technology 98, 2485-2494.

Raynaud, X., Lata, J.C., Leadley, P.W., 2006. Soil microbial loop and nutrient uptake by plants, a test using a coupled C,N model of plant-microbial interactions. Plant and Soil 287, 95-116.

Romero, E., Fernández-Bayo, J., Díaz, J.M.C., Nogales, R., 2010. Enzyme activities and diuron persistence in soil amended with vermicompost derived from spent grape marc and treated with urea. Applied Soil Ecology 44, 198-204.

Rousk, J., Bååth, E., 2011. Growth of saprotrophic fungi and bacteria in soil. FEMS Microbiology Ecology 78, 17-30.

Roy, S., Arunachalam, K., Dutta, B.K., Arunachalam, A., 2010. Effect of organic amendments of soil on growth and productivity of three common crops viz Zea mays, Phaseolus vulgaris and Abelmoschus esculentus. Applied Soil Ecology 45, 78-84.

Sakamoto, K., Oba, Y., 1994. Effect of fungal to bacterial biomass ratio on the relationship between $\mathrm{CO}_{2}$ evolution and total soil microbial biomass. Biology and Fertility of Soils 17, 39-44.

Satchell, J.E., Martin, K., 1984. Phosphatase activity in earthworm faeces. Soil Biology \& Biochemistry 16, 191-194.

Scalise, A., Tortorella, D., Pristeri, A., Petrovičová, B., Gelsomino, A., Lindström, K., Monti, M., 2015. Legume-barley intercropping stimulates soil $\mathrm{N}$ supply and crop yield in the succeeding durum wheat in a rotation under rain fed conditions. Soil Biology \& Biochemistry 89, 150-161.

Sharma, K., Garg, V.K., 2018. Chapter 17 - Solid-State Fermentation for Vermicomposting, A Step Toward Sustainable and Healthy Soil. In: Pandey, A., Larroche, C., Soccol C.R., eds. Current Developments in Biotechnology and Bioengineering: Current Advances in Solid-State Fermentation pp. 373-413.

Singh, D., Suthar, S., 2012. Vermicomposting of herbal pharmaceutical industry waste, Earthworm growth, plant-available nutrient and microbial quality of end materials. Bioresource Technology 112, 179-185.

Singh, H., Reddy, S., 2011. Effect of inoculation with phosphate solubilizing fungus on growth and nutrient uptake of wheat and maize plants fertilized with rock phosphate in alkaline soils. European Journal of Soil Biology 47, 30-34.

Srivastava, P.K., Gupta, M., Upadhyay, R.K., Sharma, S., Shikha, Singh, N., Tewari, S.K., Singh B., 2012. Effects of combined application of vermicompost and mineral fertilizer on the growth of Allium cepa L. and soil fertility. Journal of Plant Nutrition and Soil Science 175, 101-107.

Tejada, M., Benitez, C., 2011. Organic amendment based on vermicompost and compost, Differences on soil properties and maize yield. Waste Management \& Research 29, 1185-1196.

Tejada, M., García-Martínez, A.M., Parrado, J., 2009. Effects of a vermicompost composted with beet vinasse on soil properties, soil losses and soil restoration. Catena 77, 238-247.

Tejada, M., Gómez, I., Hernández, T., García, C., 2010. Utilization of vermicomposts in soil restoration, Effects on soil biological 
properties. Soil Science Society of America Journal 74, 525-532.

Thirukkumaran, C.M., Parkinson, D., 2000. Microbial respiration, biomass, metabolic quotient and litter decomposition in a lodgepole pine forest floor amended with nitrogen and phosphorous fertilizers. Soil Biology \& Biochemistry 32, 59-66.

Uz, I., Sonmez, S., Tavali, I.E., Citak, S., Uras, D.S., Citak, S., 2016. Effect of vermicompost on chemical and biological properties of an alkaline soil with high lime content during celery (Apium graveolens L. var. dulce Mill.) production. Notulae Botanicae Horti Agrobotanici Cluj-Napoca 44, 280-290.

Verma, R.K., Verma, R.S., Rahman, L.U., Yadav, A., Patra, D.D., Kalra, A., 2014. Utilization of distillation waste based vermicompost and other organic and inorganic fertilizers on improving production potential in geranium and soil health. Communications in Soil Science and Plant Analysis 45, 141-152.

Villar, I., Alves, D., Mato, S., 2017. Product quality and microbial dynamics during vermicomposting and maturation of compost from pig manure. Waste Management (New York, N.Y.) 69, 498-507.

Walkley, A.J., Black, C.A., 1934. An estimation of the Degtjareff method for determining soil organic matter and a proposed modification of the chromic acid titration method. Soil Science 37, 29-38.

Wang, P., Zhan, S., Yu, H., Xue, X., Hong, N., 2010. The effects of temperature and catalysts on the pyrolysis of industrial wastes (herb residue). Bioresource Technology 101, 3236-3241.

Wang, Y., Xu, Y., Li, D., Tang, B., Man, S., Jia, Y., Xu, H., 2018. Vermicompost and biochar as bio-conditioners to immobilize heavy metal and improve soil fertility on cadmium contaminated soil under acid rain stress. Science of the Total Environment 621, 1057-1065.

Xu, X., Xie, J., Hou, Y., He, P., Pampolino, M.F., Zhao, S., Qiu, S., Johnston, A.M., Zhou, W., 2015. Estimating nutrient uptake requirements for rice in China. Field Crops Research 180, 37-45.

Yang, L., Zhao, F., Chang, Q., Li, T., Li, F., 2015. Effects of vermicomposts on tomato yield and quality and soil fertility in greenhouse under different soil water regimes. Agricultural Water Management 160, 98-105.

Zeng, X., Shao, R., Wang, F., Dong, P., Yu, J., Xu, G., 2016. Industrial demonstration plant for the gasification of herb residue by fluidized bed two-stage process. Bioresource Technology 206, 93-98.

Zhou, H., Zhang, D., Wang, P., Liu, X., Chenga, K., Lia, L., Zheng, J., Zhang, X., Zheng, J., Crowley, D., Zwieten, L., Pan, G., 2017. Changes in microbial biomass and the metabolic quotient with biochar addition to agricultural soils: A Meta-analysis. Agriculture, Ecosystems \& Environment 239, 80-89.

Zhu, Z., Ge, T., Luo, Y., Liu, S., Xu, X., Tong, C., Shibistova, O., Guggenberger, G., Wu, J., 2018. Microbial stoichiometric flexibility regulates rice straw mineralization and its priming effect in paddy soil. Soil Biology \& Biochemistry 121, 67-76.

Zuo, Y., Zhang, J., Zhao, R., Dai, H., Zhang, Z., 2018. Application of vermicompost improves strawberry growth and quality through increased photosynthesis rate, free radical scavenging and soil enzymatic activity. Scientia Horticulturae 233, 132-140. 